\title{
Vita Sancti Wilfridi: selected aspects of language
}

\author{
Helena Polehlová
}

\begin{abstract}
Written before 720, Vita Sancti Wilfridi by Eddius Stephanus is a significant work of early AngloLatin hagiography. The article attempts to summarize the results of thorough analysis of the selected part of the Vita (chapters 1-32) from the point of view of its morphology and syntax. Typical features are illustrated on excerpts from the Vita and compared with those of the Frankish hagiography Vita vel passio Haimhrammi episcopi et martyris Ratisbonensis by Arbeo of Freising. The analysis and comparison of selected features of morphology and syntax aim to prove the relatively high level of Medieval Latin in the 8th-century Britain.
\end{abstract}

\section{Key words}

hagiography; Anglo-Latin literature; Wilfrid; Eddius Stephanus; Arbeo Frisingensis; morphology; syntax

\section{Introduction}

Written most probably between 710 and 720 (as the editor and historians agree), Vita Sancti Wilfridi ${ }^{1}$ by Eddius Stephanus is a significant work of early Anglo-Latin hagiography, roughly contemporary with earliest anonymous Anglo-Latin lives of saints - Vita Sancti Gregorii and Vita Sancti Cuthberti. As Bertram Colgrave says (1985: p. ix), "it is almost the earliest considerable piece of literature written in this country (England)." However, Vita Sancti Wilfridi seems to be unique for two reasons: although belonging to the genre of hagiography, it gives a chronological account of bishop Wilfrid's life, highlighting his career of a bishop as well as Wilfrid's repeated deposition from his see and his appeals to the pope in Rome. Surprisingly, the Vita does not depict many miracles, which usually form a substantial part of saints' lives, and thus it is perceived by some historians rather as a commemorative biography standing at the border between

1 Ed. B. Colgrave in The Life of Bishop Wilfrid (1985). The title is referred to as Vita Wilfridi or VW in the present article. To read the Czech translation of selected chapters, see Polehlová \& Polehla (2012). 
hagiography and history. In this perspective, Vita Wilfridi is presented by Bershin (1996: p. 617) as one of the Early-Medieval Anglo-Latin biographies.

The second reason for its uniqueness is the frequency of biblical quotations, paraphrases and references. As usual in hagiography, the saints' life is compared to biblical characters and events, and contrasted with them because "the substance of the holy is contained fully in Christ; the saints partake wholly of this substance but contain this substance only as accident. Yet, because they all share the same substance, they are fundamentally alike, despite their accidental differences," as stated by Heffernan (1988: pp. 11-12). This occurrence of biblical models is also reflected in the syntax of the text as will be seen below.

Not much is known about Eddius: ${ }^{2}$ Bertram Colgrave (the editor of the Life of Bishop Wilfrid) identifies him with a monk from Canterbury, an excellent singing master, who accompanied Wilfrid on his journey to Northumbria, and later spent his monastic life in Ripon (1985: p. x). However, opinions on Eddius's identity differ, e.g. Lapidge (1996: p. 14) and Goffart (2005: pp. 281ff.), so the only fact we can rely on is that he belonged to the same monastery as bishop Wilfrid and that he recorded Wilfrid's life in Vita Sancti Wilfridi.

Let us briefly introduce bishop Wilfrid: born in 634, he is considered to have been a controversial personality, a very influential man, an abbot, the bishop of York, and the main supporter and propagator of the Roman way of Christianity against the Irish way at the synod of Whitby in 664. The fact that Wilfrid spent 26 of the 46 years of his episcopate in exile speaks for itself. He is also famous for his missionary activities in the south of England, and in Frisia in the nowadays Netherlands where he spent his exile. He died in 709 or 710, and as Colgrave (1985: p. x) and Goffart (2005: p. 257) point out, The Life of Wilfrid must have been written within ten years after his death.

Research has been carried out into the first 32 chapters of Vita Wilfridi, trying to find answers to the following questions: "What is the level of Eddius's Latin? Does it indicate the relatively high level of Medieval Latin in the 8th-century Britain?" To be able to consider the veracity of the hypothesis, we have decided to compare the text with a different hagiography of a similar character and date of writing, yet of a different provenience. These requirements are met by a Frankish legend Vita vel passio Haimhrammi episcopi et martyris Ratisbonensis ${ }^{3}$ written by Arbeo, a bishop of Freising, in the second half of the 8 th century. Both hagiographies were written in the same century and both are aimed to describe the life, death and miracles of a bishop. However, one difference is obvious - as apparent from the title of Haimhramm's legend, attention is paid especially to the saint's martyrdom and his post-mortem miracles in Arbeo's hagiography.

The following part focuses on the morphology and syntax of the texts examined.

2 His name is spelled in various ways as Æddi or Æddius Stephanus.

3 Ed. B. Krusch in MGH SS rer. Mer., IV (1902: pp. 452-524). The title is referred to as Vita Haimhrammi or $\mathrm{VH}$ in the present article. 


\section{Vita Wilfridi}

\section{Analysis of morphology}

While analysing morphology, we have focused on the extent to which morphology of individual parts of speech deviates from the norm of Classical Latin. The research has been aimed at grammar categories of nouns and adjectives (declension types, case, gender), verbs (conjugation, verbal stem, voice) and the use of pronouns and prepositions.

The system of cases of nouns and adjectives appears to be mostly consistent with Classical Latin norms: gender of nouns is usually identical with that in Classical Latin and nouns usually belong to the same declension type as in Classical Latin. Changes of gender and declension type of nouns and adjectives are really only sporadic:

[1] ad decorem (VW XVII)

Predominantly, verb forms are created in accordance with the Classical Latin norms as well. The only exceptions refer to the use of active form of deponents:

[2] deosculavit (VW XVIII), minabant ( $V W$ XIX)

As much as the use of pronouns is concerned, unsystematic usage of reflexive pronouns suus, sibi, se and personal pronouns eius, ei, eum can be considered the greatest deviation from the classical norm; although the pronouns are differentiated in most cases, in some places the forms are used inconsistently, which can be attributed to the general feature of Medieval Latin: ${ }^{4}$

[3] privigna enim sibi (ei) (VW II), matre sua (eius) mortua, molesta et immitis erat (VW II); but cum mater eius in domo sua iaceret (VW I)

The use of relative pronouns also occasionally deviates from the classical norm:

[4] multiplices donationes, quam enumerare nullus potest (VW IX)

Predominantly, prepositions take the same cases of nouns and adjectives as in Classical Latin.

\section{Analysis of selected features of syntax}

As a starting point of the research several syntactic features were selected:

- Ablative absolute

$4 \quad \operatorname{Rigg~(1996:~p.~86).~}$ 
- Gerund

- Infinitive constructions

- Types of subordinate clauses

$>$ relative clauses

$>$ adverbial clauses of comparison

$>$ adverbial clauses of purpose

$>$ adverbial conditional clauses

$>$ adverbial clauses of time

> adverbial clauses of cause and reason

$>$ adverbial clauses of result

$>$ adverbial clauses of concession

$>u t$-clauses

$>$ quod-clauses

\section{Syntactic features of phrases}

\section{Ablative absolute}

Time relations are expressed not only through the use of time clauses. To the contrary, the most effective means of expressing time relations in Vita Wilfridi is ablative absolute. In fact, as is generally known, ablative absolute may express various relations, those of cause, condition, concession, and others. However, in Vita Wilfridi ablative absolute is predominantly used to express simultaneity or anteriority of the action in relation to the action of the main clause. The use of ablative absolute with imperfective active participle greatly outnumbers the same construction with perfective passive participle.

Ablative absolute also expresses a commonplace employed abundantly in hagiographies, that of God's help, blessing, and divine guidance:

[5] Deo adiuvante (VW II, XIV, XIX, XX, XXVIII), Deo concedente (VW IX), Domino dirigente ( $V W \mathrm{XXVIII})$, Deo praeviante $(V W \mathrm{XXX})$

\section{Gerund}

Although gerund is not a frequent feature of Eddius's Latin, it is used in the same way as in the Classical one. The use of the ablative of gerund for imperfective active participle, which is typical of Medieval Latin, can also be attested:

[6] navigando ad Hiberniam insulam pervenit (navigans). 


\section{Infinitive constructions}

Although in Medieval Latin texts subordinate clauses often replace infinitive constructions, in Vita Wilfridi there are numerous examples of accusative and infinitive constructions. Active and passive present infinitives as well as perfect infinitives, both active and passive ones, are used:

[6] Putabant [...] illum esse sanctum Wilfrithum episcopum. (VW XXV)

[7] Deprecor vestram beatitudinem ut [...] petitionem excipi coramque relegi praecipiatis. $(V W \mathrm{XXIX})$

[8] episcopum subterfugientem, quem huc venisse arbitrati sunt. (VW XXIX)

Nominative and infinitive constructions usually occur rarely in Medieval Latin texts. Actually, there are only two examples in chapter XXIX, both sharing the same nominative:

[9] Wilfrithus [...] prae foribus nostri secretarii esse narratus est; [...] cum petitione quam secum afferre dictus est. ( VW XXIX)

So far we have been concerned with syntactic features of sentence constituents, despite the infinitive clauses bordering on higher syntactic units. Now let us focus on the specific types of subordinate clauses.

\section{Types of subordinate clauses}

Although in Medieval Latin texts parataxis usually predominates over hypotaxis, in Vita Wilfridi there is a great number of complex sentences with subordinate clauses: the most frequently occurring clauses are relative clauses introduced by relative pronouns in a wide range of forms and containing both indicative and subjunctive forms of all verb tenses.

Adverbial clauses of comparison are rather numerous, but taking the purpose of hagiography into consideration, the relatively high number of occurrences is not surprising. These are introduced by the conjunction $u t$ or sicut and the only verb mood used is indicative, especially imperfect and perfect.

The second most numerous are purpose clauses with conjunctions $u t$ and $u t n e$. The conjunction $n e$ is used only once, in paraphrasing a biblical quotation (Gal 2, 2), where there is the conjunction $n e$ in accordance with the text of Vulgate. On the one hand, the double form of the conjunction deviates from the Classical Latin rules, on the other hand, subjunctive forms used in the clauses perfectly correspond to the rules of Classical Latin grammar (there are present and imperfect subjunctives).

Apparently, conditional clauses are introduced by si, nisi and exceptionally dum; there are both indicative and subjunctive forms in the clauses, depending on the modality. 
Generally, verb forms used in Vita Wilfridi are consistent with the Classical Latin norm.

As has already been mentioned, time relations are expressed most frequently by means of ablative absolute; however, time clauses introduced by time conjunctions also occur. The conjunctions are cum temporale, postquam, priusquam, usquedum, antequam, dum and iamiamque. What appeared surprising was rather a rare occurrence of cum when compared with occurrences of other conjunctions. The verb forms present in this type of clauses are both indicative and subjunctive forms depending on the context of the clauses. The most frequent combination is imperfect subjunctive mood in the time clause and perfect indicative mood in the main clause. The research has proved that cum temporale in clauses containing indicative mood of verbs was replaced by cum historicum; such clauses use exclusively the subjunctive mood of verbs. ${ }^{5}$

Adverbial clauses of cause and reason are introduced by the conjunction quod or quia, exceptionally with quamobrem. Predominantly, it is indicative mood of verbs which is used in such clauses. The relations of cause and reason are much more often expressed by means of coordinating conjunctions nam and enim in main clauses.

Another type of clauses is result clauses, introduced exclusively by $u t$. Main clauses often contain adverbs ita and tam referring to the result clause. Verb forms range from indicative to subjunctive mood depending on the context.

Clauses of concession are not numerous. Not surprisingly, the conjunctions employed are quamvis and licet:

[10] [...] tres in mea ecclesia sese promoverunt episcopos, licet canonica eorum non sit promotio. $(V W \mathrm{XXX})$

Depending on the tense of the main clause, present or imperfect subjunctive mood is usually employed. The mentioned example is extracted from a direct speech in which Wilfrid is defending himself in the presence of the pope. The present subjunctive possibly refers to the fact valid at the time of Wilfrid's defence, although the relation of tenses does not seem logical: imperfect subjunctive could be expected instead.

\section{Ut-clauses}

$U t$ is frequently employed in clauses dependent on main clauses containing verbs of volition (verba voluntatis): ${ }^{6}$

[11] Ideoque rogo te, ut imponas super eum presbiterii gradum [...] (VW IX)

[12] [...] rex [...] poscens ut episcopatum susciperet [...]; eum [...] ad apostolicam sedem emisit. $(V W \mathrm{XXVIII})$

$5 \quad$ Rigg (1996: p. 85); Mikulová (2014: pp. 141, 143).

6 Cf. Stotz (1998: IX, §108.1). 
The verb forms occurring in them are present and imperfect subjunctive, unexpectedly also pluperfect subjunctive mood. The reason why the pluperfect subjunctive is used is probably the description of an action preceding the plot line of Vita Wilfridi:

[13] [...] miserunt nuntios [...] petentes ut eum ad se invitasset et sibi ad regem emisisset. (VW XXVIII)

\section{Quod-clauses $^{7}$}

In some cases, infinitive clauses typical of Classical Latin were substituted by finite clauses, usually introduced by the conjunction quod:

[14] [...] sciam, quod quattuordecimani sunt (VW XII) - instead of the Classical Latin construction sciam eos quattuordecimanos esse.

[15] [...] audivit, quod praedonis more episcopus alterius episcopi sedem praeeripere ausus sit. $(V W \mathrm{XV})$

Regarding the use of tenses, serious deviations from the classical norm were expected as the text was written in the area where a Germanic language was spoken and according to Rigg (1996: p. 87), the inexact use of tenses was often influenced by the native language. However, in Vita Wilfridi, the use of tenses seems to be almost consistent with the Classical Latin criteria.

\section{Vita vel passio Haimhrammi episcopi et martyris Ratisbonensis}

\section{Analysis of morphology}

When examining the morphology of Arbeo's hagiography, we have found out that the inconsistencies with the Classical Latin norm are rather numerous and much more significant than in Vita Wilfridi. Therefore it was necessary to focus separately on morphology of nouns and adjectives, and on that of verbs and pronouns.

\section{Morphology of nouns and adjectives}

The deviations can be classified as changes of gender and/or declension type [16], attraction in noun and adjective endings or in the endings of two nouns linked co-ordinately

7 Cf. Stotz (1998: IX, §103). 
[17], attraction in prepositional constructions [18], and the use of inappropriate case of nouns modifying adjectives and verbs [19].

[16] caelus (VH XXXIV), superficies coopertus (VH VI), de scelo (VH XXXVI), sopolam (sobolem) (VH XII)

[17] collectu spiritu (VH XIX), corpus deductus (VH XX), in stagnis et amnis (VH VI), orationis et vigiliis intentus $(\mathrm{VH} \mathrm{XX})$

[18] ad pedibus (ad pedes) (VH IX), sub pastoralis curae (VH XXXVI), ex caritatis causae (VH $\mathrm{XV}$ ), in tanti viri corporis praesentiae (VH XXXV)

[19] orbati tanti pontifices (VH X), instructus operandi peritiae (VH XXXVII); sometimes the use of cases oscillates between two potential cases: huius criminis noxius (VH IX), huius innoxius crimine (VH XI); omnibus latibulis perlustrare (VH VIII), gementium condolere (VH IX)

\section{Morphology of pronouns}

Regarding pronouns, the most significant deviation from the norm can be seen in the use of inappropriate forms of pronouns haec nefandam sententiam (VH XII), eis in stuporem verteretur (VH XXIII). As in Vita Wilfridi personal and possessive pronouns se and suus frequently replace forms of is and eius; however, in some places they are differentiated. Another feature is the excessive use of enclitic -que with pronouns.

\section{Morphology of verbs}

This is another field in which deviations from Classical Latin norm can be illustrated. These relate especially to the change of verbal stems [20], use of active forms for passive ones [21], use of active form of deponents [22], which is commented on by Rigg (1996: p. 83), very frequent use of deponent forms of non-deponent verbs [23], prefixing of verbs [24], and finally, the way passive forms of pluperfect indicative and subjunctive mood are formed [25]:

[20] ab incognitis detulta viris (delata) (VH XXIII), vellisset (voluisset) (VH XXXVI), intulere (inferre) (VH XV), poposcere (poscere) (VH VIII)

[21] nuncupantem (nuncupatam) (VH XIII), condisse (condita esse) (VH XXIII)

[22] gradere (gradi) (VH XXI), imitare (imitari) (VH XXII), pollicebat (pollicebatur) (VH IV) 
[23] cessabatur (cessabat) (VH XVIII), mutare deberentur (mutari deberent) (VH XXXV)

[24] dinoscitur, depraesentetur, diiudicer ( $V H \mathrm{XV})$

[25] adstrictus fuisset ( $\mathrm{VH} \mathrm{V})$

\section{Analysis of syntax of phrases}

\section{Ablative absolute}

Time relations are expressed mainly by means of subordinate time clauses; nevertheless, it is also ablative absolute constructions which are employed, using both imperfective active participle and perfective passive participle. Their formation and usage is totally consistent with that of Classical Latin. Concerning their occurrence, they appear less frequently than in Vita Wilfridi.

\section{Gerund}

Despite being a frequent syntactic device consistent with the Classical Latin norm, gerund (and occasionally gerundive) is sometimes substituted by infinitives as in example [26]. On the other hand, gerund is used in a clause following the verb simulare where an accusative - infinitive clause would be expected [27]. The confused treatment of gerund and gerundive is mentioned by Rigg (1996: p. 85).

[26] occasionem egredere (egrediendi) (VH XII), haec tradendum non est, sed magis propheticum imitare testimonium (imitandum) (VH XXII)

[27] episcopus se limina simulat quaerendi (VH XII); se cuiusdam rei quasi expectandi simulat ( $\mathrm{VH}$ XII)

As stated above, the use of ablative gerund for imperfective active participle is typical of Medieval Latin. It is also used in Vita Haimhrammi abundantly.

\section{Infinitive constructions}

The research has shown that Arbeo's Latin oscillates between the use of infinitive constructions and the use of subordinate clauses (ut-clauses and quod-clauses) after the main clause containing verba dicendi, sentiendi and putandi. On the one hand, infinitive constructions are fully consistent with Classical Latin rules: it is especially the accusative

- infinitive construction which is employed after verba dicendi and also after imperso- 
nal constructions. Interestingly enough, personal pronoun $s e$ as the accusative element is usually not omitted, e.g. (VH IV, V, VI, XII, XIX). The rare nominative - infinitive construction is employed exclusively after videri ( VH V, VI, VIII). On the other hand, it is subordinate clauses which are governed by the main clause containing both verba dicendi and verba sentiendi or an infinitive clause introduced with the $u t$ conjunction as exemplified in [28]:

[28] praesciebat, ut impetrare potuisset (VH IX); videtur, ut refrigeres pectus (VH XIX); dixisse, ut quispiam ad mortem festinare minime debere (VH XIX)

Rarely, the quod conjunction is also used to introduce this type of clauses, e.g. (VH II, XXIII).

Other deviations from the Classical Latin form consist in agreement attraction and in inconsistencies regarding the use of tenses and an excessive use of pluperfect forms both indicative and subjunctive. ${ }^{8}$

\section{Types of subordinate clauses}

The most frequent type of subordinate clauses is relative clauses. They are introduced by various forms of relative pronouns; there are occasional lapses in agreement. The forms used are both indicative and subjunctive of present, imperfect, perfect and pluperfect tense.

Another type of clauses is those introduced with the $u t$ conjunction (ut-clauses), exceptionally with quod. As stated above, they are used as an alternative of Classical Latin infinitive constructions. They usually contain subjunctive forms of present and imperfect tenses, exceptionally also pluperfect tense. A frequent expression synonymous to the impersonal construction constat is datur intelegi. Let us focus on clauses following the main clause containing dubium non est: unlike in Classical Latin, which uses a subordinate clause introduced with quin, it is the accusative - infinitive construction which is used in Vita Haimhrammi:

[29] censorem adesse dubium non est (VH XV); membra condere dubium non est (VH XXIII)

Adverbial clauses of purpose are introduced by $u t$ and ne conjunctions and they contain subjunctive forms of present, imperfect and pluperfect tenses; analogously, clauses of result contain independent subjunctive (imp. and plpf.) and $u t$ conjuction.

As frequent in hagiographies, there are also adverbial clauses of comparison which present the author's comments such as ut diximus, ut erat dignus, ut potuit, ut erant docti. Obviously they contain indicative forms of verbs. 
Another type of clauses is the conditional ones, introduced with si and acsi. The verb forms occurring in them are consistent with Classical Latin norm and the verb forms of the clauses of concession do not deviate from the norm either. The only conjunction used is quamvis.

Clauses of causes and reason are introduced with quia most often, sometimes also with quod, cum causale and dum. The verb forms employed are those of indicative and subjunctive mood of tenses following consecutio temporum. They also depend on the probability of the cause.

A closer attention should be paid to time clauses, which are very frequent in hagiography. The most common conjunction is dum. These clauses express either simultaneity with the action of the main clause, using imperfect subjunctive forms, or anteriority, employing pluperfect subjunctive forms. Indicative forms in consecutio temporum are rather rare. Another conjunction used is cum historicum - they contain imperfect subjunctive forms to express simultaneity and pluperfect subjunctive for anteriority. Less common are postquam, quamdiu and $u t$ (as soon as). They are followed by indicative verb forms. What is important, time relations are also expressed through ablative absolute - suadente diabolo, eo meditante, his abeuntibus; sublato corpore, intermisso spatio, facto consilio; nevertheless, they are less frequent than in Vita Wilfridi.

\section{The comparison of selected features of morphology and syntax of Vita Wilfridi and Vita vel passio Haimhrammi episcopi et martyris}

As follows from the analysis of both texts, the greatest differences consist in morphology: the language of Eddius's Vita Wilfridi does not significantly deviate from Classical Latin norm in this respect; on the contrary, the Latin of Vita Haimhrammi shows substantial deviation in the inflectional system of nouns and adjectives and in the category of gender. The texts also differ in the use of prepositions: on the one hand, nouns and adjectives are governed by prepositions in accordance with the classical norm in Vita Wilfridi; on the other hand, the tendency in Arbeo's Latin to use inappropriate cases in prepositional phrases is evident. Moreover, the use of the preposition infra for intra is considered to be a typical feature of Medieval Latin (Rigg: p. 87). As stated, both hagiographies use personal pronouns se and sibi and the possessive suus inconsistently.

Far less evident differences are to be found in the comparison of the syntax: both the hagiographies attest similar syntactic devices - ablative absolute constructions, gerund, infinitive constructions and a wide range of subordinate clauses. However, the differences consist in their frequency: whereas the time relations are expressed through ablative absolute most often in Vita Wilfridi, the participial constructions are less frequent in Vita Haimhrammi, and it is mainly subordinate clauses that express the time relations. Conversely, it is gerund which is used more often in Arbeo's Latin, though inconsistently. Infinitive constructions occur in both the texts, especially governed by verba dicendi, sentiendi and putandi. The nominative - infinitive construction is rare and it is used exclusively after the main clause containing videri. As much as the subordinate clauses are 
concerned, the range of them is identical in both hagiographies. The greatest difference is evident in the use of conjunctions of these clauses, e.g. dum in Arbeo's time clauses, acsi in conditional clauses or $u t$ in subordinate clauses governed by verba dicendi and sentiendi in the main clause unlike quod in these clauses created by Eddius in Vita Wilfridi.

The substantial difference seems to consist in the great consistence of Eddius's syntax with Classical Latin norm and, at the same time, the clear deviation in Arbeo's Vita Haimhrammi in the violation of agreement in grammatical number of the subject and predicate, and also inconsistencies of tenses, which are considered by Rigg to be a frequent feature of Medieval Latin (1996: p. 87).

\section{Conclusion}

Taking the comparison of the texts into consideration, the research has proved the great difference in the level of the Medieval Latin of the Anglo-Latin Vita Wilfridi and the Frankish Vita vel passio Haimhrammi episcopi et martyris; the morphology and syntax of the former being consistent with the Classical Latin norm, with minor exceptions, the latter text proving substantial deviation from the Classical norm especially in terms of morphology, thus using what Rigg calls "ungrammatical Latin" of the pre-Carolingian Germany (1996: p. 89). Therefore, it can be said that the level of Eddius's Latin is rather high, attesting the consistency with the classical Latin norm.

\section{Bibliography}

\section{Primary Sources}

Arbeo, Vita vel passio Haimhrammi episcopi et martyris Ratisbonensis. (1902). Ed. B. Krusch. In Idem (Ed.), Passiones vitaeque sanctorum aevi Merovingici (MGH SS rer. Mer., IV, pp. 452-524). Hannoverae et Lipsiae: Hahn.

Eddius Stephanus, Vita Sancti Wilfridi. (1985). Ed. B. Colgrave. In Idem (Ed.), The Life of Bishop Wilfrid (2nd edition). Cambridge: Cambridge University Press.

\section{Secondary Sources}

Bershin, W. (1996). Biography. In F. A. C. Mantello, \& A. G. Rigg (Eds.), Medieval Latin: An Introduction and Bibliographical Guide (pp. 607-617). Washington, D.C.: The Catholic University of America Press.

Förster, J. (2007). Arbeo z Freisingu: Život a umučeni svatého Jimrama, mučednika. Praha: Karolinum. Goffart, W. (2005). The Narrators of Barbarian History. Notre Dame: University of Notre Dame Press.

Heffernan, T. J. (1988). Sacred Biography: Saints and Their Biographers in the Middle Ages. Oxford: OUP. 
Lapidge, M. (1996). Anglo-Latin Literature 600-899. London - Rio Grande: The Hambledon Press. Lapidge, M. (2014). 8. století. In C. Leonardi (Ed.), Středověká latinská literatura (6.-15. století): Př́ručka (pp. 70-100). Praha: Academia.

Mikulová, J. (2014). Syntax latinských vedlejších vět. Brno: Masarykova univerzita.

Polehlová, H., \& Polehla, P. (2012). Non Angli sed angeli. Kult svatých v latinské literatuře raně středověké Anglie. Červený Kostelec: Pavel Mervart.

Rigg, A. G. (1996). Morphology and Syntax. In Idem, \& F. A. C. Mantello (Eds.), Medieval Latin: An Introduction and Bibliographical Guide (pp. 83-92). Washington, D.C.: The Catholic University of America Press.

Stotz, P. (1998). Handbuch zur lateinischen Sprache des Mittelalters: Formenlehre, Syntax und Stilistik. (Bd. 4). München: C. H. Beck.

Townsend, D. (1996). Hagiography. In F. A. C. Mantello, \& A. G. Rigg (Eds.), Medieval Latin: An Introduction and Bibliographical Guide (pp. 618-628). Washington, D.C.: The Catholic University of America Press.

Mgr. Helena Polehlová / helena.polehlova@uhk.cz

Department of Classical Studies

Masaryk University, Faculty of Arts

Arna Nováka 1, CZ-602 00 Brno, Czech Republic 
